\title{
Assessment of Water Quality Status of Water Bodies Using Water Quality Index and Correlation Analysis in and Around Industrial Areas of West District, Tripura, India
}

\author{
Bishu Karmakar $†$ and Mahesh Kr. Singh \\ Department of Chemistry, Tripura University, Suryamaninagar, Tripura, India \\ †Corresponding author: Bishu Karmakar; bishuk5@gmail.com
}

Nat. Env. \& Poll. Tech. Website: www.neptjournal.com

Received: $25-04-2020$

Revised: 29-06-2020

Accepted: 13-07-2020

Key Words:

Industrialisation

Water quality index

Seasonal variations

Surface water

\begin{abstract}
Industrialization, urbanisation and agricultural development cause pollution in water bodies due to the discharge of wastewater directly or indirectly. The present study aims to assess the water quality of water bodies in and around A D Nagar, Badharghat, Dukli and Budhjungnagar Industrial Estates, West Tripura during pre-monsoon and post-monsoon in the year 2016 to 2018 . Biological parameters namely DO, BOD, Total Coliform, Faecal Coliform and COD, Physico-chemical parameters namely $\mathrm{pH}$, EC, TDS, Bicarbonates, Chlorides, Sulphates Total Hardness, Calcium, Magnesium etc. and heavy metals were analysed using standard methods as prescribed by APHA. The analysed parameters were compared with the standards prescribed by BIS. The BOD values for all the water bodies were beyond the prescribed standard limit except the pond located at the southern side of Jutemill, Hapania (S-3) during pre-monsoon season. The Total Coliform values for water bodies located at the eastern and northern side of Badharghat Industrial Estate were beyond the prescribed standard limit. The seasonal variations of water quality have also been observed. Water Quality Index values reflected that the $75 \%$ of surface water samples were of poor quality and $25 \%$ were of good quality in both the season. Correlation study revealed that positive and significant correlations between the pairs of selected parameters in surface water samples were observed. This study reveals that the surface water of these water bodies needs proper treatment before consumption and it also needs to be protected from the domestic as well as industrial contamination.
\end{abstract}

\section{INTRODUCTION}

Freshwater is essential to support the living creature as it helps in the growth of the entire living organism. The main source of freshwater comprises the lotic (rivers and streams) and lentic (ponds and lakes) water bodies. The rising population, industrialisation and urbanisation change the quality of freshwater. Generally, these resources are degrading gradually due to anthropogenic impacts, lack of awareness among people and lack of legal and institutional framework (Gulia et al. 2017, Pavan \& Banerjee 2015). The water bodies, especially ponds are generally small in size but these are valuable sources of water in rural areas for the purpose of domestic, irrigation, fisheries etc. The rainwater is one of the main sources of such village ponds. The water of ponds is being polluted mainly due to discharge of wastes from the residential area, sewage outlets, detergents, automobiles oil waste and industrial wastewater (Ancy \& Shaji 2016). In India, approximately $70 \%$ of water becomes contaminated due to the release of domestic sewage and industrial effluents into freshwater bodies (Sheetal \& Sudan 2017). It is very much important to know the quality of water before its consumption since the consumption of water containing impurities will cause various water-borne diseases. From the literature survey, it has been found that there is no water quality report of freshwater bodies in and around the A. D. Nagar, Badharghat, Dukli and Budhjungnagar industrial estates. Therefore, the present study was designed to assess the status and quality of selected pond water.

\section{STUDY AREA}

The West Tripura district is the largest among the eight Districts of Tripura and lies approximately between latitude $23^{\circ} 16^{\prime}$ to $2414^{\circ}$ ' north and longitude $9109^{\circ}$ ' to $9147^{\circ}$ ' east having an area of approximately $983.63 \mathrm{sq} . \mathrm{km}$. and population of 9.17 lakhs as per Census India, 2011. The major four industrial estates such as A.D. Nagar (8.41 acres), Badharghat (20.525 acres), Dukli (45.77 acres) and Bodhjungnagar Industrial Estate (535.73 acres) are located in the West Tripura District. The three industrial estates such as A.D. Nagar, Badharghat, Dukli Industrial Estate are located in the urban area nearer to Agartala, State capital and the 
distance between these estates are very less. The Bodhjungnagar Industrial Estate is located in a rural area that is far away from the Agartala [TIDC]. The industries such as distillery, rubber-based unit, waste recycling units, thermal power plants, steel rolling plant, food processing, stone crusher, brick kilns, dairy, automobile, pharmaceuticals, rubberwood treatment, spices, tyre \& tube, hot mix plant, latex processing, cattle feed etc. are found in the study areas and have high water pollution potential (Singh \& Karmakar 2017). The details of sampling locations and study maps are illustrated in Table 1 and Fig. 1 respectively.

\section{MATERIALS AND METHODS}

In the present study, the sampling was done during morning hour ( 8 am to $9 \mathrm{am}$ ) in the month April-May (pre-monsoon) and October-November (post-monsoon) in the year 2016 to
2018. The water samples were collected in hard polyethene bottles of 1.5 litre capacity with stopper. Each bottle was washed with $2 \%$ nitric acid and then rinsed three times with distilled water (Khwaja \& Aggarwal 2016). The samples were collected from three different points and were mixed to prepare an integrated sample. After sample collection, some physical, as well as chemical reactions, would change the quality of the water sample; therefore to minimize this change the samples were preserved as early after the collection. The water samples were preserved by adding chemical preservatives and by lowering the temperature (Kumar et al. 2014). The temperature was measured by thermometer immersed directly in the water body. The parameters like $\mathrm{pH}$, Electrical Conductivity (EC), Total Dissolved Solids (TDS) were measured in situ using the potable HI 98130 Combo pH/ EC/ TDS meter (Hanna Instruments). The Dissolved Oxygen was fixed instantly on the spot and analysed immediately

Table 1: Details of sampling locations in and around A D Nagar, Badharghat and Dukli and Budhjungnagar Industrial Estates.

\begin{tabular}{|c|c|c|c|}
\hline Sample No & Locations & Latitude & Longitude \\
\hline \multicolumn{4}{|c|}{ A D Nagar, Badharghat and Dukli Industrial Estates } \\
\hline S-1 & Pond located at eastern side of Badharghat Industrial Estate & $\mathrm{N} 23^{\circ} 47^{\prime \prime} 44^{\prime} \mathrm{N}$ & $\mathrm{E} 91^{\circ} 16^{\prime \prime} 10^{\prime} \mathrm{E}$ \\
\hline $\mathrm{S}-2$ & Pond located at northern side of Badharghat Industrial Estate & $\mathrm{N} 23^{\circ} 47^{\prime /} 51^{\prime} \mathrm{N}$ & $\mathrm{E} 91^{\circ} 16^{\prime \prime} 12^{\prime} \mathrm{E}$ \\
\hline S-3 & Pond located southern side of Jutemill, Hapania & $\mathrm{N} 23^{\circ} 47^{\prime /} 1^{\prime} \mathrm{N}$ & $\mathrm{E} 91^{\circ} 16^{\prime \prime} 5^{\prime} \mathrm{E}$ \\
\hline S-4 & Pond, Chowhan Para, Dukli & $\mathrm{N} 23^{\circ} 47^{\prime \prime} 3^{\prime} \mathrm{N}$ & $\mathrm{E} 91^{\circ} 17^{/ /} 32^{\prime} \mathrm{E}$ \\
\hline \multicolumn{4}{|c|}{ Budhjungnagar Industrial Estate } \\
\hline S-5 & Community Pond, ADC Birbal Para & $\mathrm{N} 23^{\circ} 53521 \mathrm{~N}$ & E $91^{\circ} 22741 \mathrm{E}$ \\
\hline S-6 & Pond, Rajchantai & $\mathrm{N} 23^{\circ} 53567 \mathrm{~N}$ & E $91.22730 \mathrm{E}$ \\
\hline S-7 & Pond, Laxmipur, Dulal Debnath & N $23^{\circ} 51724 \mathrm{~N}$ & $\mathrm{E} 91^{\circ} 20588 \mathrm{E}$ \\
\hline S-8 & Lake, Rajarband & $\mathrm{N} 23^{\circ} 52550 \mathrm{~N}$ & E $91^{\circ} 20348 \mathrm{E}$ \\
\hline
\end{tabular}
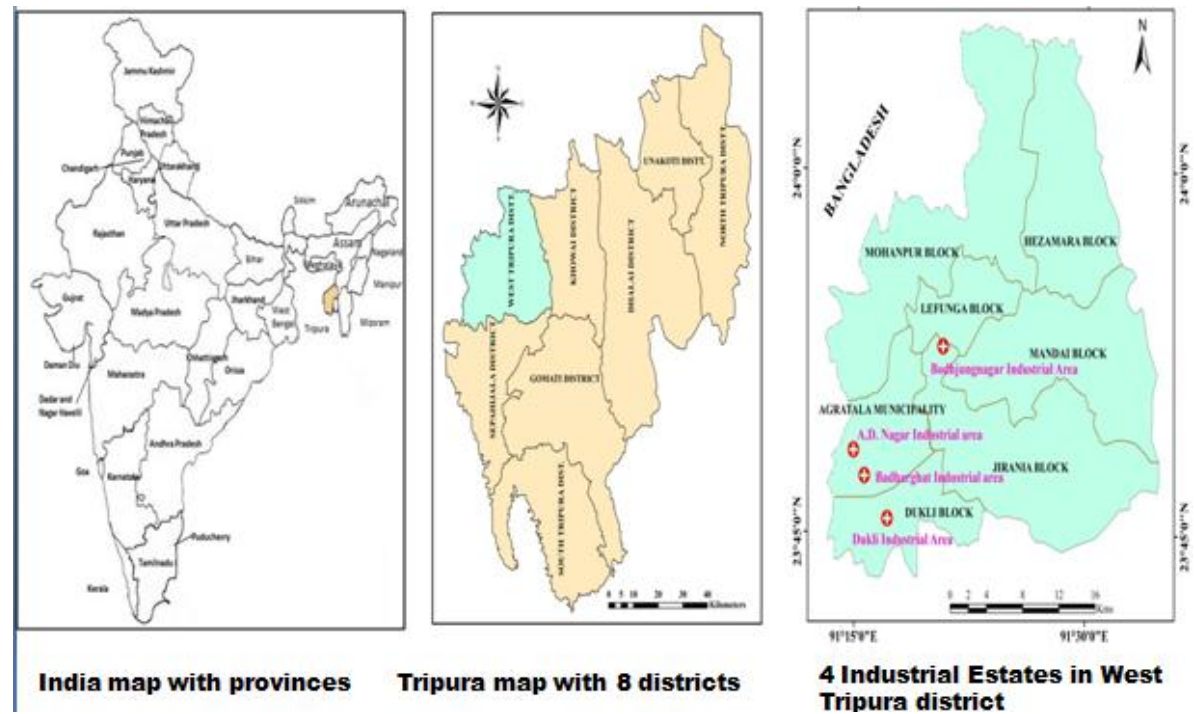

Fig. 1: Map showing the A D Nagar, Badharghat, Dukli and Budhjungnagar Industrial Estates in West Tripura district, India. 
as per Wrinkler's method with Azide modification. BOD was measured followed by incubation of BOD bottle at $21^{\circ} \mathrm{C}$ for 5 days. COD was determined by the potassium dichromate open reflex method. Total Coliform and Faecal Coliform were determined by the Multiple Test Tube method. Turbidity was measured by a Nepthalo turbidity meter. Total Hardness, calcium $(\mathrm{Ca})$ and magnesium $(\mathrm{Mg})$ were measured complex-metrically, chloride $\left(\mathrm{Cl}^{-}\right)$was measured following argento-metric analysis and sulphate $\left(\mathrm{SO}_{4}{ }^{2-}\right)$ and phosphate was measured by spectrophotometer (Thermo fisher: Evolution 201), fluoride ( $\mathrm{F}^{-}$) was measured colourimetrically. Heavy metals were analysed using atomic absorption spectrophotometer (Perkin Elmer AAS 700). The other parameters were analysed by using the standard methods Prescribed by APHA (APHA 2005). The quantitative analytical data are presented in Table 2 . Water quality indices have been calculated for every selected location of the study areas to assess the drinking water quality. Correlation analysis was also carried out for the water quality data to predict the inter-relationship between the parameters.

Water Quality Index: Water Quality Index (WQI) represents a large number of water quality data to a single numerical value. It signifies the composite influence of various water quality parameters on the overall quality of water (Ramakrishnaiah et al. 2009). In this study, the water quality index has been calculated considering selected important parameters. The WQI has been calculated by using the standards of drinking water quality recommended by the BIS (BIS 1991). Three steps have been followed to calculate WQI. In the first step, selected parameters have been assigned a weight (wi) according to its relative importance in the assessment of drinking water quality. The weightage has been given to the parameters according to their importance in water quality assessment.

In the second step, the relative weight (Wi) is calculated with the help of the following equation:

$$
\mathrm{Wi}=\mathrm{wi} / \sum_{\mathrm{i}=1}^{\mathrm{n}} \mathrm{wi}
$$

Where, $\mathrm{Wi}$ is the relative weight, wi is the weight of each parameter and $\mathrm{n}$ is the number of parameters.

In the third step, a quality rating scale (qi) for each parameter is calculated by the following equation:

$$
\mathrm{qi}=(\mathrm{Ci} / \mathrm{Si}) \times 100
$$

Where, $\mathrm{Ci}$ is the concentration of each chemical parameter in each water sample in $\mathrm{mg} / \mathrm{L}$, and $\mathrm{Si}$ is the Indian drinking water standard for each chemical parameter in $\mathrm{mg} / \mathrm{L}$.
Using the relative weight and quality rating scale values SI for each parameter is calculated. WQI is thus calculated using the equation mentioned below:

$$
\begin{aligned}
& \mathrm{SI}_{\mathrm{i}}=\mathrm{Wi} \cdot \mathrm{qi} \\
& \mathrm{WQI}=\Sigma \mathrm{SI}_{\mathrm{i}}
\end{aligned}
$$

Correlation coefficient: Correlation represents the degree of mutual relationship among two variables. The correlation coefficient (r) is the percentage of difference in the dependent variable explained by the independent variables. The positive sign or values signify the positive correlation correspondingly negative values signify the negative correlation between two variables (Magroliya et al. 2018).

The relationship between two parameters was established by calculating Karl Pearson's correlation coefficient, r, by using the formula as given

$$
r=\frac{x \sum x y-\sum x \sum y}{\sqrt{n \sum x^{2}}-\left(\sum x\right)^{2} \sqrt{n \sum y^{2}}-\left(\sum y\right)^{2}} \ldots
$$

Where $\mathrm{r}=$ Karl Pearson's correlation coefficient, $y=$ Dependent variable, $x=$ Independent variable and $\mathrm{n}=$ Number of Observations. If the correlation coefficient is closed to +1 or -1 predicts a good relationship between two variables $\mathrm{x}$ and $y$, and the correlation coefficient $r=0$ predicts no relationship between two variables. The correlation between the parameters is considered as strong, when it is in the range of +0.8 to 1.0 and -0.8 to -1.0 , moderate when it is having a value in the range of +0.5 to 0.8 and -0.5 to -0.8 , weak when it is in the range of +0.0 to 0.5 and -0.0 to -0.5 (Saxena et al. 2016 and Heydari et al. 2013).

\section{RESULTS AND DISCUSSION}

The season-wise minimum, maximum, mean and standard deviation values of the water quality parameters are given in Table 2. The results were compared with drinking water standards [BIS].

The $\mathrm{pH}$ values varied between 6.27 to 7.36 with a mean of 6.83 during pre-monsoon and 6.01 to 6.86 with a mean of 6.39 during post monsoon seasons. The $\mathrm{pH}$ value was in decreasing trend from pre-monsoon to post-monsoon which may be due to the dilution of rainwater (Rashmi 2016). Electrical conductivity is the ability of an aqueous solution to pass electric current which depends on ions and their total concentration, mobility and temperature. The EC values recorded were in the range of 84.67 to $224 \mu \mathrm{Scm}^{-1}$ with a mean of $154.17 \mu \mathrm{Scm}^{-1}$ during pre-monsoon and 104 to $190.7 \mu \mathrm{Scm}^{-1}$ with a mean of $153 \mu \mathrm{Scm}^{-1}$ during post-monsoon seasons. The high EC value indicates the presence of salts and ions in higher concentration (Bajpai et al. 2012). Turbidity is the measure of the light scattered 
Table 2: Physico-Chemical Characteristics of Pond water in and around A D Nagar, Badharghat, Dukli and Budhjungnagar Industrial Estate *Units of all the parameter are in $\mathrm{mg} / \mathrm{L}$ except $\mathrm{pH}, \mathrm{EC}\left(\mu \mathrm{Scm}^{-1}\right)$ and Turbidity (NTU).

\begin{tabular}{|c|c|c|c|c|c|c|c|c|}
\hline \multirow[t]{2}{*}{ Parameters } & \multicolumn{4}{|c|}{ Pre monsoon } & \multicolumn{4}{|c|}{ Post monsoon } \\
\hline & Min & Max & Mean & SD & Min & $\operatorname{Max}$ & Mean & SD \\
\hline Temperature & 26 & 27 & 26.46 & \pm 0.33 & 25.17 & 25.38 & 25.42 & \pm 0.23 \\
\hline $\mathrm{pH}$ & 6.27 & 7.36 & 6.83 & \pm 0.49 & 6.01 & 6.86 & 6.39 & \pm 0.35 \\
\hline $\mathrm{EC}$ & 84.67 & 224 & 154.17 & \pm 50.44 & 104.7 & 190.7 & 153 & \pm 32.64 \\
\hline TSS & 16 & 40 & 26.67 & \pm 9.27 & 19.33 & 42 & 30.25 & \pm 7.47 \\
\hline TDS & 48 & 134 & 96.92 & \pm 31.35 & 66.67 & 130 & 97.54 & \pm 22.30 \\
\hline Turbidity & 33.05 & 197.67 & 84.46 & \pm 53.08 & 36.34 & 197.7 & 88.88 & \pm 51.74 \\
\hline $\mathrm{TH}$ & 38.86 & 51.31 & 44.83 & \pm 4.48 & 44.85 & 59.78 & 51.87 & \pm 4.98 \\
\hline Total N & 17.77 & 41.35 & 25.86 & \pm 8.05 & 18.73 & 43.93 & 27.45 & \pm 8.19 \\
\hline DO & 5.18 & 6.45 & 5.75 & \pm 0.38 & 5.29 & 6.23 & 5.66 & \pm 0.29 \\
\hline BOD & 3.51 & 4.7 & 4.08 & \pm 0.45 & 3.77 & 4.98 & 4.46 & \pm 0.41 \\
\hline COD & 24.67 & 36.67 & 29.67 & \pm 3.89 & 28 & 34.67 & 31.25 & \pm 2.51 \\
\hline $\mathrm{TC}$ & 376.7 & 520 & 447.92 & \pm 56.96 & 426.7 & 540 & 484.17 & \pm 38.70 \\
\hline $\mathrm{FC}$ & 220 & 283.3 & 255.83 & \pm 24.48 & 253.3 & 353.3 & 298.33 & \pm 38.38 \\
\hline $\mathrm{HCO}_{3}$ & 25.84 & 105.1 & 54.43 & \pm 30.71 & 29.25 & 89.26 & 52.51 & \pm 24.28 \\
\hline $\mathrm{Cl}$ & 13.7 & 22 & 19.44 & \pm 2.72 & 15.37 & 25.14 & 21.35 & \pm 2.96 \\
\hline $\mathrm{SO}_{4}$ & 10.89 & 28.77 & 19.03 & \pm 5.75 & 13.23 & 31.19 & 20.88 & \pm 6.15 \\
\hline $\mathrm{PO}_{4}$ & 0.14 & 0.73 & 0.34 & \pm 0.24 & 0.2 & 1.1 & 0.44 & \pm 0.33 \\
\hline $\mathrm{NO}_{3}$ & 0.25 & 2.12 & 0.99 & \pm 0.74 & 0.26 & 2.66 & 1.21 & \pm 0.98 \\
\hline $\mathrm{Na}$ & 1.63 & 25.82 & 7.18 & \pm 8.85 & 1.79 & 29.86 & 8.11 & \pm 10.13 \\
\hline $\mathrm{K}$ & 0.55 & 15.36 & 3.39 & \pm 5.14 & 0.62 & 17.06 & 3.78 & \pm 0.96 \\
\hline $\mathrm{Ca}$ & 7.12 & 9.1 & 8.24 & \pm 0.75 & 7.96 & 10.64 & 9.39 & \pm 0.98 \\
\hline $\mathrm{Mg}$ & 4.42 & 7.23 & 5.84 & \pm 1.08 & 5.23 & 7.97 & 6.82 & \pm 1.08 \\
\hline $\mathrm{F}$ & 0.19 & 0.4 & 0.30 & \pm 1.08 & 0.21 & 0.39 & 0.32 & \pm 0.07 \\
\hline $\mathrm{Fe}$ & 0.71 & 3.41 & 1.68 & \pm 0.93 & 0.76 & 3.39 & 1.76 & \pm 0.98 \\
\hline $\mathrm{Mn}$ & 0.1 & 0.81 & 0.27 & \pm 0.26 & 0.12 & 0.79 & 0.28 & \pm 0.24 \\
\hline $\mathrm{Pb}$ & 0.01 & 0.026 & 0.02 & \pm 0.01 & 0.01 & 0.024 & 0.02 & \pm 0.01 \\
\hline $\mathrm{Cd}$ & 0.002 & 0.007 & 0.004 & \pm 0.002 & 0.001 & 0.01 & .0005 & \pm 0.003 \\
\hline As & 0.0002 & 0.019 & 0.01 & \pm 0.01 & 0.0004 & 0.027 & 0.01 & \pm 0.01 \\
\hline $\mathrm{Cu}$ & 0.02 & 0.05 & 0.03 & \pm 0.01 & 0.017 & 0.05 & 0.03 & \pm 0.01 \\
\hline $\mathrm{Zn}$ & 0.04 & 0.45 & 0.19 & \pm 0.16 & 0.04 & 0.4 & 0.18 & \pm 0.14 \\
\hline $\mathrm{Cr}$ & 0.02 & 0.04 & 0.03 & \pm 0.01 & 0.017 & 0.037 & 0.03 & \pm 0.01 \\
\hline
\end{tabular}

by suspended particles. The clay, silt, organic matter, phytoplankton and other microscopic organisms cause turbidity in pond water. Turbidity ranged from 33.05 to $197.67 \mathrm{NTU}$ and 36.34 to 197.7 during pre-monsoon and post-monsoon seasons respectively. The maximum turbidity in water was recorded during post monsoon season which may be due to accumulation of sand, clay, silt, dung and various other pollutants along with rainwater from the surrounding area (Kumar et al. 2014). The oxygen can be dissolved in water from air or is formed by the photosynthetic organism like algae and aquatic plants. The oxygen is poorly soluble gas in water and its solubility depend on the temperature of the water and its partial pressure. The minimum and maximum dissolved oxygen were recorded as $5.18 \mathrm{mg} / \mathrm{L}$ and $6.45 \mathrm{mg} / \mathrm{L}$ respectively during pre-monsoon season. BOD refers to the oxygen used by the microorganism in the aerobic oxidation of organic matter. Therefore with the increase in the amount of organic matter in the water the BOD increases. The BOD value ranged between 3.51 to 4.7 and 3.77 to 4.98 during pre-monsoon and post-monsoon seasons respectively. The BOD values of all the water samples were beyond the standard limit (BIS: $3 \mathrm{mg} / \mathrm{L}$ ) in both seasons. The BOD value of 
post monsoon season was more than pre monsoon season because of the presence of several microbes in water bodies, which accelerate their metabolic activities with the increase in concentration (Kumar et al. 2014). The Total Coliform numbers per $100 \mathrm{~mL}$ of water ranged from 376.7 to 520 and 426.7 to 540 during pre-monsoon and post monsoon respectively. Total Coliform count was increased from pre-monsoon to post-monsoon. The high concentration of organic matter of Faecal origin possibly arises from the industrial activities as well as residential inhabitants. Total hardness values ranged from 38.86 to $51.31 \mathrm{mg} / \mathrm{L}$ during pre-monsoon and to 44.85 to $59.78 \mathrm{mg} / \mathrm{L}$ during post-monsoon. $\mathrm{TH}$ is used to describe the effect of dissolved minerals (mostly calcium and magnesium) determining suitability of water for domestic, industrial and drinking purpose attributed to the presence of ferrous iron, bicarbonates, sulphates, chloride and nitrate of calcium and magnesium. High values of hardness are probably due to regular addition of large quantities of detergents used by the nearby residential localities which drain into the water bodies. The hard water can cause indigestion problem and possibilities of forming calcium oxalate crystals in urinary tracts (Deepa et al. 2016). Calcium and magnesium levels were found increased during post monsoon than pre monsoon seasons. The concentration of iron in the water samples varies from 0.71 to $3.41 \mathrm{mg} / \mathrm{L}$ and 0.76 to $3.39 \mathrm{mg} / \mathrm{L}$ during pre-monsoon and post-monsoon respectively. The recorded iron levels in water bodies were much higher than BIS standard. The high iron content may be due to the influence of rainfall infiltrating and dissolution of iron-bearing mineral rocks and soils which are leached into these water bodies (Sekar \& Suriyakala 2016 and Idoko 2010). The considerable content of manganese was recorded in both seasons. The concentration of other heavy metals such as lead, cadmium, arsenic, copper, zinc and chromium were within the prescribed BIS standard limits during both seasons. The remaining parameters were within the BIS standard limit but seasonal variations were observed.

Water Quality Index: The weights assigned and relative weights for each parameter was given in Table 3. The Water Quality Index classification and its values have been presented in Table 4 and Table 5 respectively. The seasonal variation of WQI and Pie diagram of overall WQI in the study areas are shown in Fig. 2 and Fig. 3 respectively.

The WQI values revealed that the surface water quality was found as a poor category in almost all sampling sites in both seasons. It may be due to the ionic leaching, overexploitation and anthropogenic activities such as discharge of effluents from industrial, agricultural and domestic uses (Jena et al. 2013). It is observed that $75 \%$ of surface water of the sampling locations are of poor quality and $25 \%$ of surface water are of good quality. This indicates that water samples of the study areas are highly polluted. They are not suitable for drinking purposes and other useful human activities. The water quality index (WQI) indicates that sampling site $\mathrm{S}-5$ is highly polluted compared to others. This site is nearer to the Budhjungnagar Industrial estate and receives more industrial effluents, wastes and sewage water.

Table 3: Relative weight of selected parameters.

\begin{tabular}{|c|c|c|c|}
\hline Parameters & Standard (BIS) & Weight (wi) & Relative Weight (Wi) \\
\hline TDS & 500 & 5 & 0.052083333 \\
\hline $\mathrm{HCO}_{3}^{-1}$ & 200 & 1 & 0.010416667 \\
\hline $\mathrm{Cl}^{-}$ & 250 & 5 & 0.052083333 \\
\hline $\mathrm{SO}_{4}^{-2}$ & 200 & 5 & 0.052083333 \\
\hline $\mathrm{NO}_{3}^{-1}$ & 45 & 5 & 0.052083333 \\
\hline $\mathrm{Ca}$ & 75 & 3 & 0.03125 \\
\hline $\mathrm{Mg}$ & 30 & 3 & 0.03125 \\
\hline $\mathrm{Na}$ & - & 4 & 0.041666667 \\
\hline $\mathrm{K}$ & - & 2 & 0.020833333 \\
\hline $\mathrm{Fe}$ & 0.3 & 5 & 0.052083333 \\
\hline $\mathrm{Cr}$ & 0.05 & 5 & 0.052083333 \\
\hline $\mathrm{Pb}$ & 0.05 & 5 & 0.052083333 \\
\hline $\mathrm{Cu}$ & 0.05 & 2 & 0.020833333 \\
\hline $\mathrm{Mn}$ & 0.1 & 5 & 0.052083333 \\
\hline $\mathrm{Cd}$ & 0.003 & 5 & 0.052083333 \\
\hline $\mathrm{Zn}$ & 5 & 1 & 0.010416667 \\
\hline $\mathrm{pH}$ & $6.5-8.5$ & 4 & 0.041666667 \\
\hline As & 0.05 & 5 & 0.052083333 \\
\hline $\mathrm{TH}$ & 300 & 3 & 0.03125 \\
\hline $\mathrm{EC}$ & 300 & 1 & 0.010416667 \\
\hline F & 1.0 & 5 & 0.052083333 \\
\hline Temp. & 40 & 1 & 0.010416667 \\
\hline Turbidity & 1 & 1 & 0.010416667 \\
\hline BOD & 3.0 & 3 & 0.03125 \\
\hline DO & 5.0 & 4 & 0.041666667 \\
\hline $\mathrm{PO}_{4}$ & - & 1 & 0.010416667 \\
\hline $\mathrm{FC}$ & - & 5 & 0.052083333 \\
\hline \multirow[t]{2}{*}{ COD } & - & 2 & 0.020833333 \\
\hline & & $\Sigma w i=96$ & $\Sigma \mathrm{Wi}=1$ \\
\hline
\end{tabular}

Table 4: WQI classification and results (Paul et al. 2016).

\begin{tabular}{|ll|}
\hline WQI Value & Water Quality \\
\hline$<50$ & Excellent \\
$50-100$ & Good \\
$100-200$ & Poor \\
$200-300$ & Very Poor \\
$>300$ & Unsuitable \\
\hline
\end{tabular}


Table 5: Water quality status based on WQI.

\begin{tabular}{|lllll|}
\hline $\begin{array}{l}\text { Location } \\
\text { No. }\end{array}$ & WQI & & & \\
\cline { 2 - 5 } & $\begin{array}{l}\text { Pre } \\
\text { Monsoon }\end{array}$ & $\begin{array}{l}\text { Water Quality } \\
\text { status }\end{array}$ & $\begin{array}{l}\text { Post } \\
\text { Monsoon }\end{array}$ & $\begin{array}{l}\text { Water Quality } \\
\text { status }\end{array}$ \\
\hline S-1 & 124.18 & Poor & 122.03 & Poor \\
S-2 & 135.33 & Poor & 139.46 & Poor \\
S-3 & 92.41 & Good & 90.30 & Good \\
S-4 & 74.79 & Good & 80.21 & Good \\
S-5 & 178.59 & Poor & 182.93 & Poor \\
S-6 & 119.60 & Poor & 123.79 & Poor \\
S-7 & 116.85 & Poor & 143.48 & Poor \\
S-8 & 122.17 & Poor & 139.37 & Poor \\
\hline
\end{tabular}

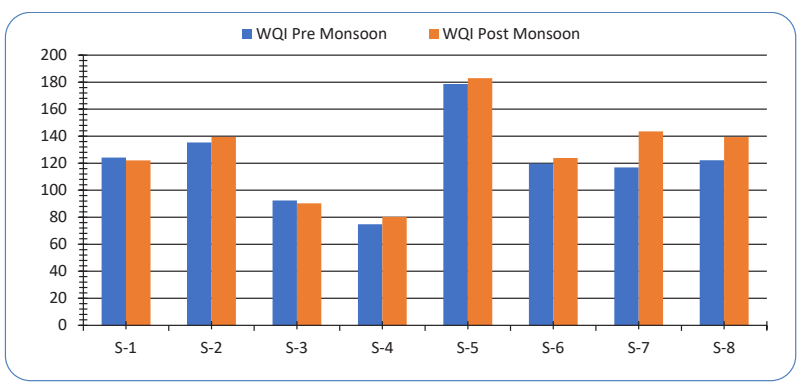

Fig. 2: Seasonal variation of WQI.

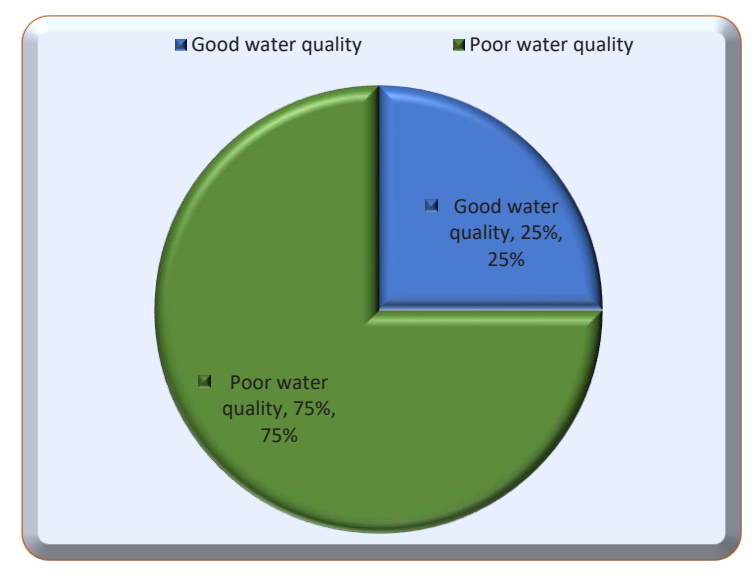

Fig. 3: Pie diagram of overall WQI.

Correlation analysis: The season-wise correlation coefficient (r)values are shown in Table 6 and Table 7 respectively. During pre-monsoon, Electrical conductivity was strongly correlated with TDS $(+0.8142)$. Total Nitrogen was strongly correlated with $\mathrm{PO}_{4}(+0.8865)$ and $\mathrm{NO}_{3}(0.9360)$. $\mathrm{HCO}_{3}$ was strongly correlated with $\mathrm{Na}(+0.8372)$ and $\mathrm{K}(+0.8073)$. Sodium was strongly correlated with K $(+0.9750)$. During post monsoon, Electrical conductivity was moderately correlated with TDS (+0.6179), $\mathrm{HCO}_{3}(+0.6573), \mathrm{Na}(+0.5997)$, $\mathrm{K}(+0.5638)$ and BOD was strongly correlated with COD
$(+0.8742)$ and Total Coliform $(+0.8742)$ and $\mathrm{HCO}_{3}$ was strongly correlated with $\mathrm{Na}(+0.8313))$. During post monsoon DO was moderately negatively correlated with BOD $(-0.5227)$ which signifies that BOD increases then DO will also decrease (Indu et al. 2015). TDS and EC are positively correlated because electrical conductivity is dependent on the dissolved ions. EC increases with the high value of TDS (Dhamodharan \& Shanthakumar 2016). The hardness of water samples is positively correlated with the ions namely bicarbonate, chloride, sulphate, nitrate, sodium, potassium, calcium, and magnesium which determine that the surface water of the study areas are hard water (Sen et al. 2011).

\section{CONCLUSION}

The analytical data of water samples reveal that all the parameters show slight seasonal variations. It has been observed that the values of surface quality parameters of the study area are higher during the post-monsoon period reflecting the effect of monsoon and clearly indicated seasonal variation. The water quality indices (WQI) were in the range 74.79 to 182.93 and it is observed that $75 \%$ of surface water of the sampling location are of poor quality and $25 \%$ of surface water is of good quality. The bacteriological load in the water bodies was the main reason for its poor water quality. The application of the Water Quality Index (WQI) in this study has been found very useful in assessing the overall quality of water. The correlation study on water quality parameters showed that some of the parameters are correlated with each other. It is observed that some of the parameters have a positive or negative correlation between them. This study reveals that the surface water of these waterbody areas needs proper treatment before consumption. These water bodies need to be protected from domestic as well as industrial contamination. The promotion of an awareness campaign among industry owners as well as local people is required to maintain good water quality. The protection, conservation and rejuvenation of water bodies must be treated as an important national as well as international issue. This study may be used by the government policymakers as well as industrial entrepreneurs as baseline information regarding surface water quality in the industrial areas of the West Tripura district to take pollution control measures.

\section{ACKNOWLEDGEMENT}

The authors are thankful to the Head, Department of Chemistry, Tripura University for providing infrastructural facilities for carrying out the research work. The authors also acknowledge the help received from the Chairman, Tripura State Pollution Control Board for extending laboratory facilities for analytical works. 


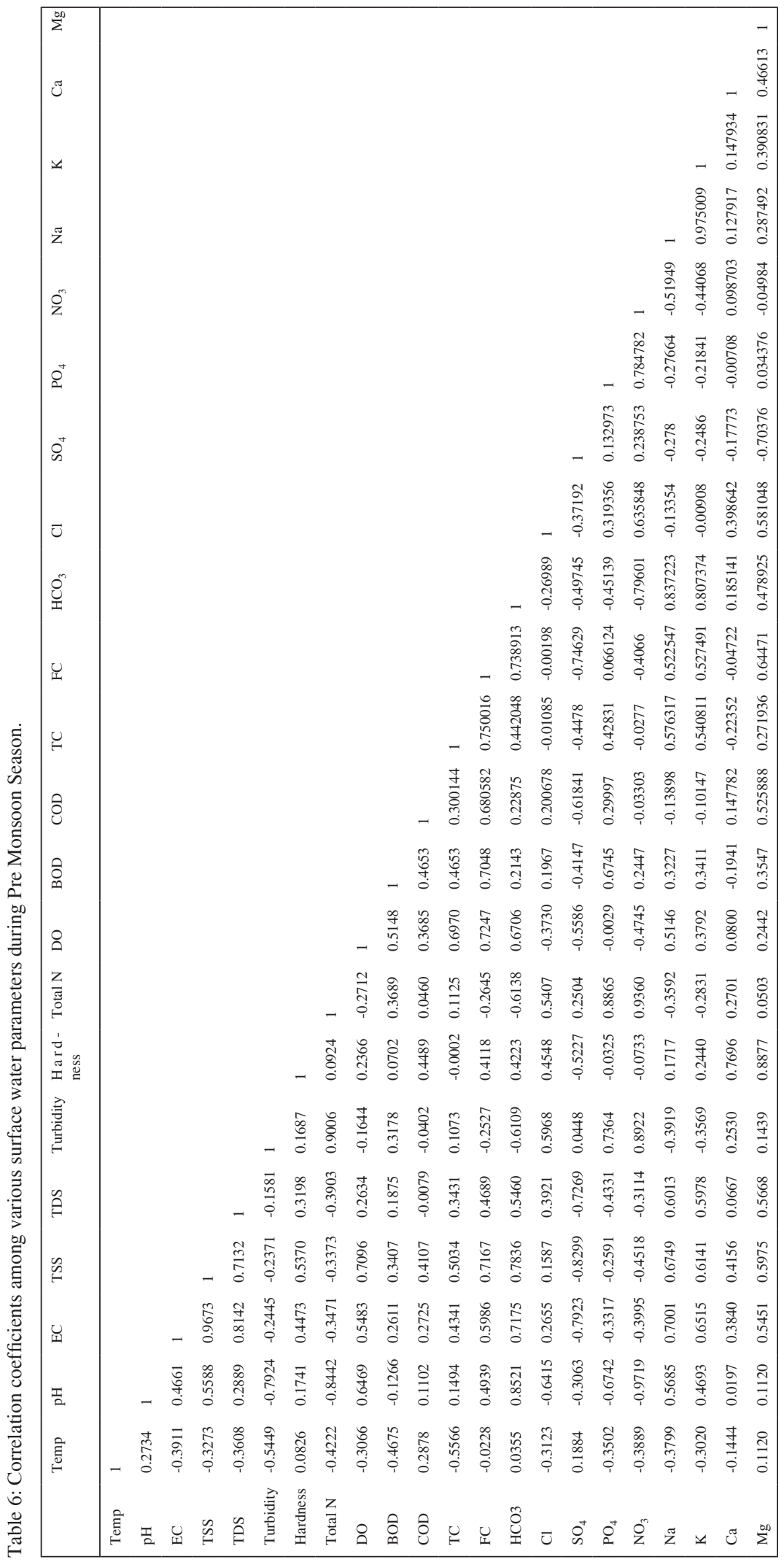




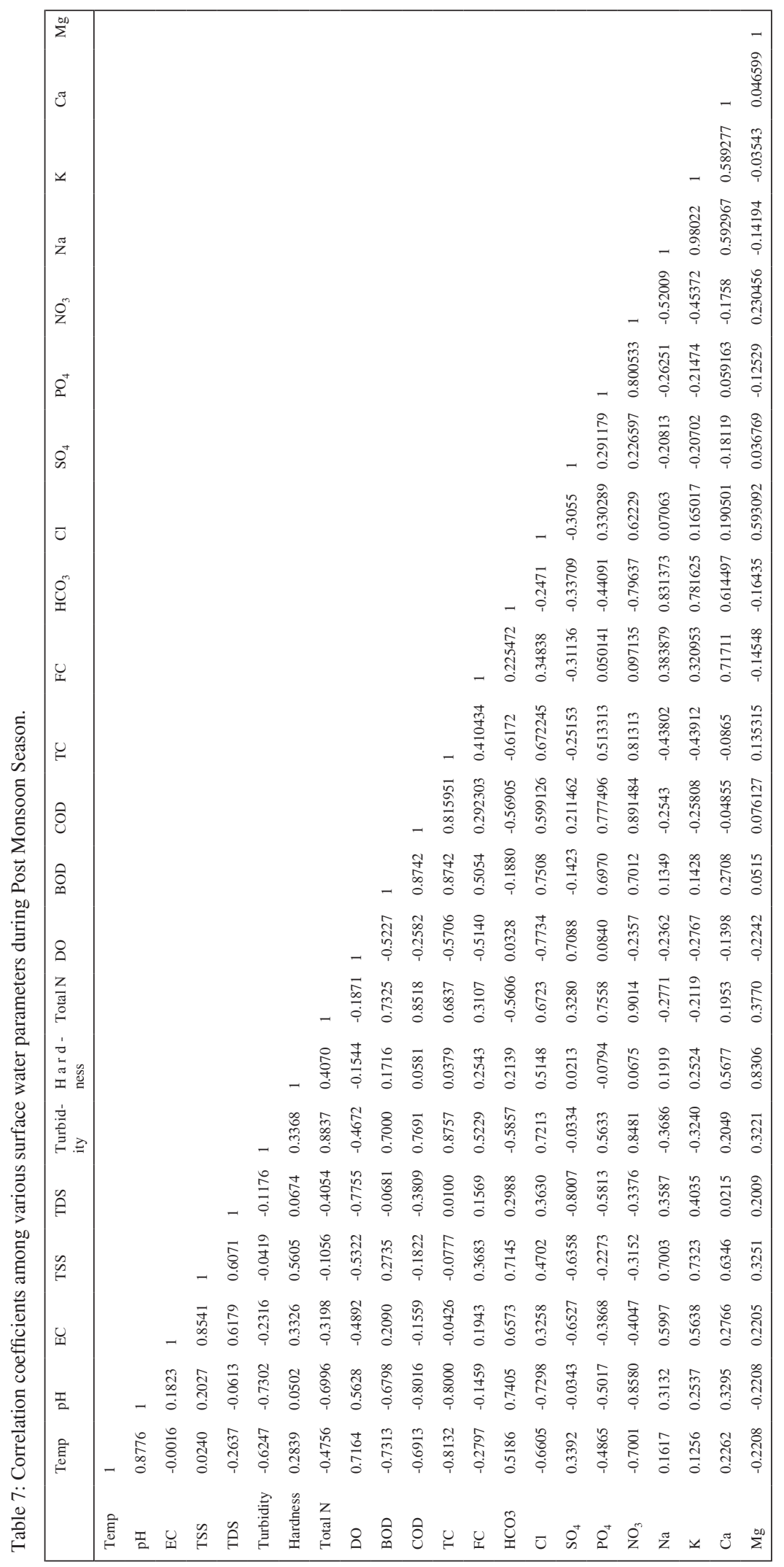




\section{REFERENCES}

APHA 2005. Standard Method of Examination of Water and Wastewater, 21st Edition, 2005.

Ancy, Mol. P. and Shaji, E. 2016. Physico-Chemical Characteristics of Surface Water Quality of Urban Ponds in Thiruvananthapuram District, Kerala, International Journal of Emerging Trends in Science and Technology, Vol.03, Issue 01, Pages 3431-3437, ISSN 2348-9480.

Bajpai, N., Sikka J. and Sharma, R. 2012. Effect of the Khan river water on chlorophyll content, carotenoids and enzyme activities of Ipomoea fistulosa and Polygonum barbatum. Nature Environ. and Pollution Tech., 11(2): 319-323.

BIS, 1991. Drinking Water Specification: Bureau of Indian Standards; IS: 10500.

Deepa, P., Raveen, R., Venkatesan, P., Arivoli, S. and Samuel, T. 2016. Seasonal variations of physicochemical parameters of Korattur lake, Chennai, Tamil Nadu, India. International Journal of Chemical Studies, 4(3): 116-123.

Dhamodharan, A. and Shanthakumar, S. 2016. Assessment of seasonal variations in surface water quality of Cooum river in Chennai, India - a statistical approach. Global NEST Journal, 18(X).

Gulia, S. K., Ganie, S. A. and Yadav S. S. 2017. Studies on seasonal variations in some physiochemical parameters of the village ponds of Jhajjar District (Haryana), India. Plant Archives, 17(1): 271-281.

Heydari, M. M., Ali, A., Seyed, M.R. and Seyed, Mohammad, A.H. 2013. Correlation study and regression analysis of drinking water quality in Kashan City, Iran, Middle-East. Journal of Scientific Research, 13(9): 1238-1244.

Idoko, O.M. 2010. Seasonal variation in iron in rural ground water of Benue State, Middle belt, Nigeria. Pakistan Journal of Nutrition, 9(9): 1680-5194.

Indu, Abhimanyu Singh \& Raveesh Chandra 2015. Study on physicochemical parameters and correlation analysis of surface water of Nawabganj Lake. International Journal of Current Research, 7(08).

Jena, V., Dixit, S. and Gupta, S. 2013. Assessment of water quality index of industrial area surface water samples. International Journal of Chem. Tech. Research, 5(1): 278-283.

Khwaja, M. Anwar and Aggarwal, V. 2016. Studies on seasonal variation in ground water quality: a statistical approach. Journal of Environmental Research and Development. 11(01).
Kumar, S., Roshni Adiyecha and Tarun Patel 2014. Seasonal variation in the water quality of Lahru pond located in Himachal Pradesh. Int. Journal of Engineering Research and Applications, 4(3): 507-513.

Magroliya, Vasundhara and Trivedi, M. 2018. Statistical correlation and seasonal comparative study of groundwater samples of Jaipur. Environ. Risk Assess. Remediate, 2(3).

Paul, R., Das, S., Nag, S.K. and Singh, M.K. 2016. Deciphering groundwater quality for drinking and irrigation purposes -a study in Lefunga block of West Tripura district, Tripura, India. Journal of Earth Science \& Climatic Change, 7(12).

Pavan, M. and Benarjee, G. 2015. Studies on physico-chemical parameters and occurrence of heavy metals in an Urban lake of Warangal district during different seasons. International Journal of Plant, Animal and Environmental Sciences, 5(3).

Ramakrishnaiah, C. R., Sadashivaiah, C. and Ranganna, G. 2009. Assessment of water quality index for the groundwater in Tumkur Taluk, Karnataka State, India. E-Journal of Chemistry, 6(2): 523-530.

Rashmi, S. 2016. Seasonal variation in physico-chemical and biological analysis of Moti Lake, Motihari, East Chamapran, Bihar. Research Journal of Chemical and Environmental Sciences, 4(5).

Saxena, S. and Saxena, U. 2016. Correlation and regression analysis of ground water of Bassi Tehsil, district Jaipur, Rajasthan, India. International Journal of Plant, Animal and Environmental Sciences, 6(1).

Sekar, K. G. and Suriyakala, K. 2016. Seasonal variation of heavy metal contamination of groundwater in and around Udaiyarpalyam taluk, Ariyalur district, Tamil Nadu. World Scientific News, 47-60.

Sen, S., Mrinal, K. P. and Borah, M. 2011. Study of some physico-chemical parameters of pond and river water with reference to correlation study. International Journal of ChemTech Research CODEN( USA): IJCRGG., 3(4): 1802-1807.

Sheetal, N. and Sudan, S. M. 2017. Water quality assessment of Rajsamand Lake, Rajasthan, India. International Research Journal of Environmental Sciences, 6(6): 22-28.

Singh, M.K. and Karmakar, B. 2017. Assessment of groundwater quality of Budhjungnagar industrial estate and A D Nagar, Dukli \& Badharghat industrial cluster of Tripura West District, Tripura State, India by water quality index method. International Journal of Scientific Research in Science and Technology, 3(8). 